
DE AUMENTAR A MOTIVAÇÃO DOS ESTUDANTES PARA APRENDER QUÍMICA

\title{
HISTORY OF CHEMISTRY AND SCIENTIFIC TOURISM AS A MEANS TO INCREASE STUDENTS MOTIVATION TO LEARN CHEMISTRY
}

\author{
Ketevan Kupatadze ${ }^{1 *}$; Giorgi Begadze ${ }^{2}$; Michael Gverdtsiteli ${ }^{3}$; \\ ${ }^{1,2}$ Ilia State University, Faculty of Arts and Sciences / Center of Tourism Management \\ 3/5, Kakutsa Cholokashvili Ave, Tbilisi 0162, Georgia \\ (Phone: +995 5992909 05; +995 5775533 32) \\ ${ }^{3}$ Iv.Javakhishvili Tbilisi State University, Faculty of Exact and Natural Sciences \\ 2, Chavchavadze Ave, Tbilisi 0179, Georgia \\ (Phone: +995 5552308 02) \\ * Corresponding author \\ e-mail: ketevan_kupatadze@iliauni.edu.ge
}

Received 05 February 2014; received in revised form 18 June 2014; accepted 18 June 2014

\section{RESUMO}

O presente artigo discute os problemas relacionados com a motivação dos estudantes para aprender Química. Os problemas mencionados são comuns para a Georgia e outros países. Como estudo de caso, o artigo irá discutir a metodologia de ensinar Química como um curso introdutório na llia State University. A metodologia é orientada na realização de alguns princípios didáticos importantes no processo de ensino que é uma ferramenta muito efetiva para aumentar a motivação dos estudantes em aprender. Introduzir os primeiros fatos históricos sobre químicos conhecidos também é interessante para os estudantes. Esse tipo de informação ajuda os estudantes a terem mais discernimento sobre essa complexa disciplina e a Química torna-se mais interessante para eles. $O$ artigo também propõe ferramentas a respeito de como conectar o processo de educação em Química com história, turismo científico e outras ciências. No final, serão demonstrados os resultados do experimento realizado pelos autores. O resultado do experimento pedagógico tornou essa isso claro, ou seja, que esse de ensino de Química afeta positivamente no que diz respeito a motivação dos estudantes e mudanças nas suas atitudes frente a disciplina.

Palavras-chave: História da Química; princípios em didática de Química, experimentos interessantes em Química; Alquimia; turismo científico.

\begin{abstract}
The present article discusses the problems related with the motivation of students to learn chemistry. The problems mentioned are common for Georgia and other countries. As a case study, the article will discuss the methodology of teaching chemistry as an introductory course at Ilia State University. The methodology is orientated on realization of some important didactic principles in teaching process which is very effective tool for increasing students' motivation to learn. Introducing foremost historical facts about the well-known chemists is very interesting for students as well. Such information helps students to get more insights about this complex discipline and chemistry becomes more interesting for them. The article also proposes the tools how to link chemistry education process with history, scientific tourism and other sciences. At the end, there will be demonstrated the results of the experiment carried out by the authors. The outcome of the pedagogical experiment has made it clear, that such a method of teaching chemistry affects positively on students motivation and changes their attitude towards the subject.
\end{abstract}

Keywords: History of chemistry; Principles in didactic of chemistry; interesting experiments in chemistry; Alchemy, scientific tourism. 


\section{INTRODUCTION}

The present article discusses the problems related with the motivation of students to learn chemistry. The problems mentioned are common for Georgia and other countries. The problems of other countries related with the chemistry education are collected by the authors from various international conferences held annually (CCECRICE 2012; CHSTM 2013).

Chemistry is multifarious discipline. Usually, students at schools and universities don't like to learn it. Through this article, we discuss the particular case of teaching chemistry: teaching chemistry to students at the University for whom chemistry is not specialization, but they must study chemistry because it is obligatory subject. It is difficult to teach chemistry to students without adequate theoretical base from school. Statistically, eight school students out of ten, considers that chemistry is not connected with their everyday life; and, that it is very dull because contains difficult incomprehensible formulas and laws. Fortunately, there are some exceptions, but the above mentioned tendency is very widespread.

The process of teaching chemistry is based on some didactic methodologies, out of which the main 3 principles are: obviousness, scientific character, accessibility. All these principles are very actual (Eilks; Hofstein. 2013)

Chemistry is an experimental science. Thus, the principle of obviousness can be realized easily [Eilks; Hofstein. 2013]. Unlike chemical theory, students (for whom chemistry is not a specialization) are enjoying experiments. Some of them prefer to have only the visual part of experiments; they don't try to understand the process of chemical mechanism. However, majority of them are interested in developing a deep understanding of the chemistry. If there was added to enquire connection between subjects and chemistry, we might receive even more motivated students to learn. The experiments are great tools to enable students to realize the principle of obviousness.

While teaching an introductory course in Chemistry, it is widely recommended to use popular oral vocabulary, the one understandable for students. Various entertaining and interesting information must become a part of the lectures as well. e.g.: using examples from history of chemistry, daily chemistry, or information from scientific tourism. By bringing parallels from other sciences, we'll achieve realization the principle of accessibility. The principle of realization of the scientific character should be implemented through the help of entertaining activities, so that chemical information, terminology, laws and reactions didn't cause the "fear" within students.

\section{MATERIALS AND METHODS}

\section{Finding}

Herewith, we would like to present the experience from the introductory courses in Chemistry at Ilia State University: During the first year of studies, students are offered to take general education courses. The module is called "General Module" and the courses - "Introductory courses". Introductory courses comprise various sciences (e.g.: humanities, technical, exact and natural, etc.). The ultimate goal of the General Module is to help students find the right profession for them.

The names of the chemistry introductory courses are disguised with intriguing titles. Because, if we named it "Chemistry", students might have skipped the course and never choose it. Therefore, the courses were given following names: "From Alchemy to $21^{\text {st }}$ century", "What secret does the vitamins have", "What is protein and what should we know about it", "What should we know about environmental pollution", "The History of chemistry". Out of the above mentioned, the first and the last introductory courses are the most popular. The reason is that we use the interdisciplinary approach. We connect the chemistry theme with something that makes chemistry more interesting for students. Such combination increases their motivation to learn. The next step is to maintain and intensify the earned motivation. That can be done through linking chemistry with everyday life. It's not surprising that many other sciences make a good use of chemistry in our century. Afterwards, we start connecting chemistry with history, scientific tourism and other interesting experiments. Such approach works well on improving students' motivation. 
Introducing foremost historical facts about the well-known chemists is very interesting for students as well. Such information helps students to get more insights about this complex discipline and chemistry becomes more interesting for them.

The introductory courses are started with the period of alchemy. Ancient Egyptian and Arabian alchemies are the most prominent within our courses. First we discuss Ptolemey, which is followed by Jābir ibn Hayyān (Geber) and Muhammad ibn Zakariyā Rāzī, etc. [Arthur Greenberg, 2007].

Ptolemy (AD 90-AD168) was known as a mathematician, astronomer, geographer, astrologer. He was a faithful friend of Alexander the Great and was the commander of Alexander's army. After the conquest of Egypt by the Alexander the Great Ptolemy was his representative in Egypt. Very soon he noticed that Egyptian priests were good at Chemeya (ancient name of chemistry; At VII ${ }^{\text {th }}$ century the Arabic article "Al" was added and name was changed into "Al chemeya" and after the first crusade name was transformed again intoAlchemy. Only at $17^{\text {th }}$ century Robert Boyle established the new name of the science -"Chemistry"). And he (Ptolemy) began gathering existing knowledge and made translation into Greek language.

With Ptolemy (figure 1) and his three sons is connected the construction of the Temple in Greek. The name of this Temple was "Museyon"the house of Muse. There was kept the ancient Manuscripts. Lately this tample was burned down.

As it was mentioned already at $\mathrm{VII}^{\text {th }}$ century Egypt was fall down by Arabic Army. And the story was repeated. All existing knowledge in chemeya was translated from Greek into Arabic language and the name-"Chemeya" was changed into "Al Chemeya".

It is worth to emphasize, in spite of Georg Stahl being called an alchemy swindler, there existed many thinkers before him.

From Arab alchemists the most prominent are Jābir ibn Hayyān (later European alchemists called him - Geber; 721 AD -815 AD) (figure 3) and Muhammad ibn Zakariyā Rāzī (later
European alchemists called him - Razes; 854 CE- 932 CE).

Muhammad ibn Zakariyā Rāzī (figure 2) like others searched for philosophic stone but only for medicine. His goal was to find the recipe for eternal youth and life. But instead this he found out Gypsum $\left(\mathrm{CaSO}_{4} \cdot 2 \mathrm{H}_{2} \mathrm{O}\right)$ and established methodology treatment for broken limbs with this salt. He wrote also "The Great book of Mystery" where all known substances was divided into three group: 1. Minerals; 2 . Substances of vegetable origin; 3 . Substances of animal origin;

What was Jābir's alchemy? He thought to transform metals into gold giving the special attention to mercury and sulfur to make it. He was aware that obtained gray powder ( $\mathrm{HgS})$ was not gold, but he believed this substance could be transformed into gold and was searching for the substance that could accelerate this transformation; and, he doesn't spend it. And, can be used repeatedly. We always put the question to what Jābir was saying. Maybe, in modern chemistry we already have such a substance, what Jābir was searching for in $7^{\text {th }}$ century? Some students answered that Jābir was searching for the philosophic stone, which is correct version. He thought that the accelerator was the powder "ixir" in Arabian (with Arabian article "al ixir". Afterwards Europeans called this "elixir" a "philosophic stone". Some student answered that it is catalyst in modern chemistry this is also a correct answer. A catalyst accelerates a chemical reaction and doesn't spend and change itself. Thus, we can use it (if it is inorganic catalyst and unfermented) in other processes. Of course a catalyst can't transform other metal into gold (even with mercury and sulfide), but Jābir didn't know it.

This part of lecture is continued by carrying out a demonstration experiments. These two experiments are more entertaining: we decompose hydrogen peroxide in the presence of potassium iodide (entertaining name is "toothpaste for elephant"); in the second case, by manganese dioxide (entertaining name is "Gin in the bottle"). Such experiments are very efficient and very useful if the student's are motivated (Figure 4). Afterwards, the essence of the catalyst pounds, through Le Chatelier principle. This information is explained together with the 
main classes of inorganic compounds [Raul Sutton, Bernard Rockett, Peter Swindells, 2008]. We have to repeat one more time that, these courses are of an introductory character and most of the students still may choose another profession. Thus, lectures and seminars must be carried out in a popular manner, with dosing scientific content and terminology. In such a way, the principle of accessibility can be realized.

Chemistry is a subject, which requires preservation of motivation. This can be achieved through the alchemy. Chemistry and alchemy can be connected with mineralogy, within the scope of the history of chemistry. The interest of the students can be encouraged by discussing the minerals which they know from everyday life. As an example we take half-precious stones which students have come across through the jewelries. We illustrate lazurite for them (it is complex compound with a cubic to triclinic crystal structure. Its chemical composition is: $\left(\mathrm{Na}_{2} \mathrm{O}\right)$ $16,8 \%, \quad(\mathrm{CaO}) \quad 8,7 \%, \quad\left(\mathrm{Al}_{2} \mathrm{O}_{3}\right) \quad 27,2 \%, \quad\left(\mathrm{SiO}_{2}\right)$ $\left.31,8 \%,\left(\mathrm{SO}_{3}\right) 34 \%,(\mathrm{Cl}) 0,25 \%\right)$. This mineral has susceptible history and was represented in Jābir's book.

What was the position of this mineral in Jābir's alchemy? In his book "The Great Book of the Properties" he has discussed the minerals. $\mathrm{He}$ was dividing them into three classes according to the behavior they had when heating:

- Bearer of spirit (arwah) where the compound completely evaporates during heating;

- Metals (ajsam) where the compound melts during heating and becomes flat under blow;

- Solid bodies (ajsad) where the compound doesn't melt during heating and doesn't become flat under blow. In this group, he described lazurite [Ferratio, 2013].

If we continue with minerals, we can include malachite as well. Thousand of legends exist about this mineral and demonstration of its decomposition turns to be a very interesting experiment.

The discovery of acids is connected with Jābir's name also. He found out Acetic acid and believed that it was the strongest solvent. The solubility table of substances was established by him but as there was known only two solvent- water and acetic acid, the majority of substances were named as insoluble.

At $14^{\text {th }}$ century the nitric acid and sulfuric acid was discovered by pseudo Jābir (by the man whos artcicles were signed as Jābir). At historical sources there is only known that he was origin from Spain.

After this discovery the solubility table was changed [Azimov, 1983].

Now, it is interesting how can chemistry be connected with such popular topic like Scientific Tourism? For the first time, the name "Scientific Tourism" can be found from 1980 in literature. It was the work of Tropical Science and Tourism. Scientific tourism was described here as a work of the explorers in the country without proper technical equipment [Laarman, J. G. and Perdue, R. R., 1989]. We argue that Scientific Tourism is a specific form of tourism related to education process (in our case chemistry education).

If we continue with the alchemy, one of the most well known alchemists of the medieval epoch is Arnold Wilanow. He has served as an alchemist at the royal doors of the king Edward II. At the same time he was the representative of the Polish Royal dynasty and his portrait can be found in the famous Palace of Wilanov near the Warsaw.

But again, how can we make a proper linkage between chemistry, history of chemistry and tourism? Do we remember an alchemist Paracelsus from the medieval ages? He was doctor and alchemists at the same time. Like Jābir and others, he was searching for the philosophical stone. But he wanted to find it not for some metal transformation into the gold, but for improving a human health with it. As a philosophical stone, several options were considered by Paracelsus: for the first time it was Zinc, the second was distilled water, third and the most convincing one was - sodium chloride. He also believed that this salt had a memory. Very good example for connecting chemistry, history and scientific tourism is information about the place in Poland Wieliczka, where there is located the cave made by pure table salt. One of the author of the article (G.Begadze), had opportunity to make this type of connection between history, chemistry and scientific tourism during his 
scientific practice tour with students in Poland (Figure 5). The same connection might be done during the domestic tourism [Begadze, 2013.].

The scenario of this connection myth can be various and can be used during the practice, at the lecture or at the laboratory. At the laboratory, it is very effective approach to run the series of experiments under the name "the Historical Experiments". The Hydrogen was discovered in XVII century, by English scientist $\mathrm{H}$. Kavendish. $\mathrm{He}$ had put the little vessel with $\mathrm{Zn}$ or $\mathrm{Fe}$ and dilute sulfuric acid in water. Isolated gas was burnt and a retort was put on it. He had noticed, that the gas burns, sometimes - explodes. On the basis of this property, Kavendish ascertained that this gas was not oxygen. He called it "combustible air". A. Lavoisier called this "air hydrogen" ("Hydrogenium"- water burner) (figure 6). The touristic place connected with Kavendish is located near Manchester Chatsworth House.

There is another intriguing way to get students involved in chemistry world. Those are legend. The beautiful Dana lives in the ancient legends. She is locked in the Fortress and in front of her windows golden raindrops start to drop down. But this was the ancient Greeks God Zeus. He came to visit Dana. Actually, we can make the experiments under the name "Golden Rain". This reaction is between potassium lodide and lead nitrate. In every country exist exotic touristy places with connection some legends (Begadze,2013) They history should be used in chemistry education process.

Together with this approach should be used as many popular information from history, touristy places or literature as possible [Kupatadze,2014].

After the students have had several lectures in chemistry, based on different topics, they become ready to prepare the presentation. Based on the knowledge obtained during the one-term introductory course, they pick up the topic which may be useful for them in the future (as for non-chemists), for their everyday life. Of course, the aim of this course is also to encourage students to choose chemistry (or related subject, like biology) as their major field of study.

While working on the presentation, students try to connect the topic with global problems, with history of chemistry, biology, tourism, etc. In addition, they try to search for information from the historical experiments and include them in their presentation. Usually, we suggest the experiments which have pushed for the new discoveries and brought to the new phenomenon. To such a category of the historical experiments belongs the reaction of decomposition of mercury oxide, when mercury and oxygen became isolated. With this reaction Priestley had discovered oxygen.

\section{RESULTS AND DISCUSSION:}

At the end of the term we had offered an anonymous questionnaire to the students. Students from three introductory courses had participated in this opinion research (about 800 students). The questionnaire contained following questions (the test is anonymous and student names are unknown, they are requested to be as honest as possible):

1) Why did you choose this introductory course:

a) The name of the course was interesting;

b) I was interested in chemistry;

c) I had heard that the course was interesting;

d) There wasn't a vacancy on other courses;

e) Other:

last answer, please, explain).

2) Has the course justified your expectations:

a) Yes;

b) No;

c) At half;

d) Other:

(If you chose the last answer, please, explain).

3) Do you think, the knowledge gained will be useful for you, as a non-chemist?

a) Yes;

b) No;

c) At half;

d) Other:

(If you chose the last answer, please, explain).

4) Did you like demonstrations of chemical experiments within the scope of the course? Did we need such experiments?

a) Yes; 
b) No;

c) Other:

(If you chose the last answer, please, explain)

5) If you would have a chance to choose this course again, which experiments would you liked to add? What kind of experiments? (Your answer will help us to develop the course in future).

6) If you would have a chance to choose this course again, which topics would you like to add? (Your answer will help us to develop the course in future).

7) Did you like an attempt to integrate the Scientific Tourism with the topics which were discussed during the course?

a) Yes;

b) No;

c) Other:

(If you chose the last answer, please, explain).

8) Did you like an attempt to integrate the history of chemistry with the topics which were discussed during the course?

a) Yes;

b) No;

c) Other:

(If you chose the last answer, please, explain).

9) Was the course represented clearly?

a) Yes;

b) No;

c) Other:

(If you chose the last answer, please, explain).

10)Had this course changed your opinion about chemistry?

a) Yes;

b) No;

c) Other:

(If you chose the last answer, please, explain).

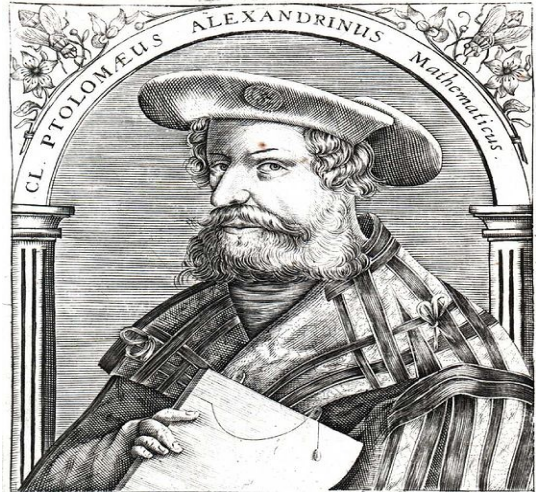

Figure 1: Ptolemy

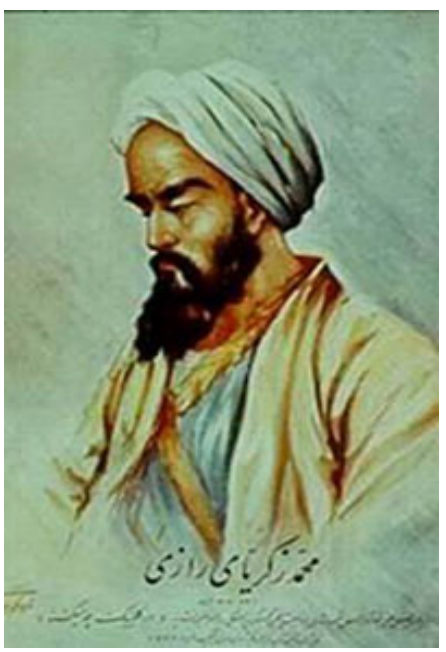

Figure 2: Muhammad ibn Zakariyā Rāzī

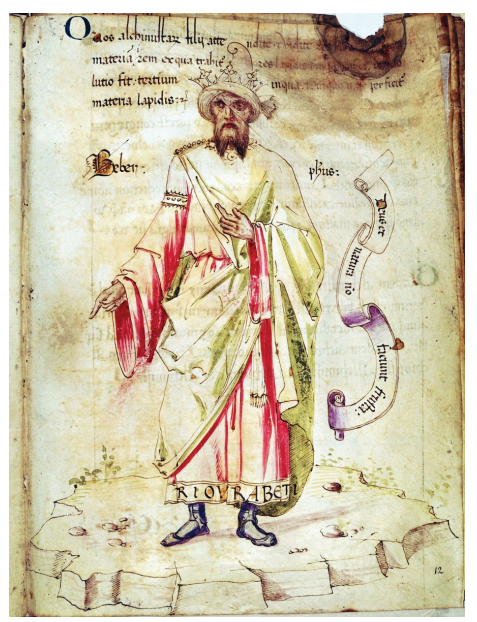

Figure 3: Jābir ibn Hayyān 


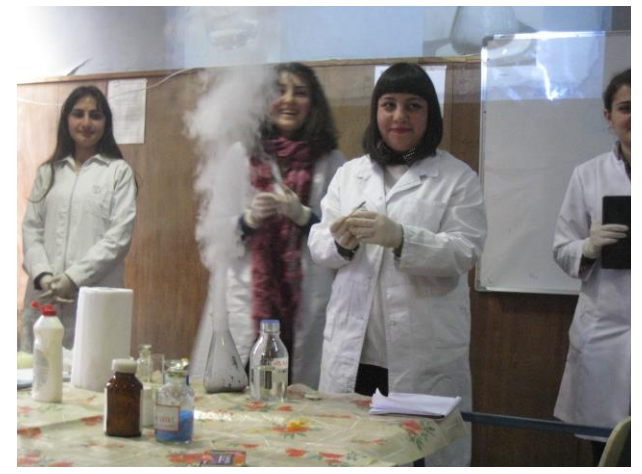

Figure 4: "Gin in the bottle"

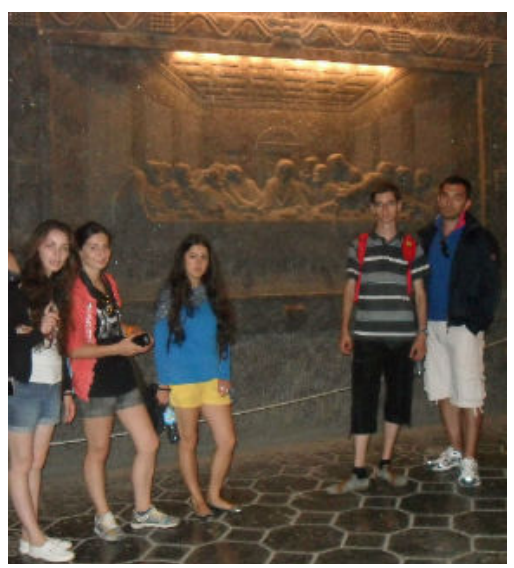

Figure 5: At the Cave of the Table Salt

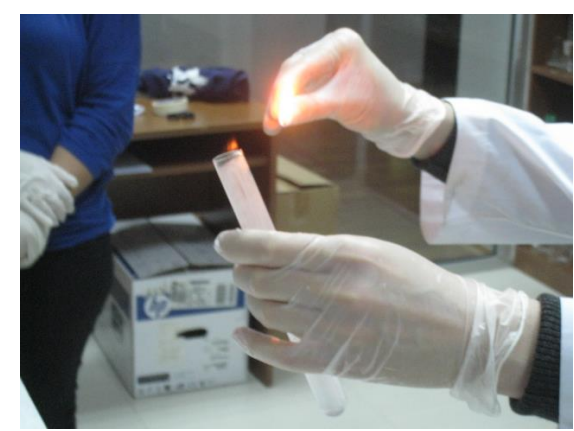

Figure 6: Experiment of H.Kavendish

\section{RESULTS}

To the question "Why did you choose this introductory course", the answers were distributed in the following way:

a) The name of the course was interesting - 234 answers;

b) I was interested in by chemistry - 0 answers; c) I had heard that the course was interesting 165 answers;

d) There wasn't a vacancy at other courses 401 answers;

e) Other - 0 answers.

To the question "Has the course justified your expectation" the answers were distributed in the following way:

a) Yes - 239 answers;

b) No - 201 answers;

c) At half - 363 answers;

d) Other -0 answers.

To the question "Do you think the knowledge gained will be useful for you, as a non-chemist", the answers were distributed in the following way:

a) Yes - 400 answers;

b) No - 200 answers;

c) At half - 200 answers;

d) Other -0 answers.

To the question "Did you like demonstrations of chemical experiments within the scope of the course? Did we need such experiments?" the answers were distributed in the following way:

a) Yes - 700 answers;

b) No - 99 answers;

c) Other - 1 answer (One student had answered that he has allergy on the odor of chemical reactive).

To the question "If you would have a chance to choose this course again, which experiments would you liked to add? What kind of experiments?" the answers were distributed in the following way: 200 students answered that they like the experiments with the explosion, 345 students - the experiments with historical backgrounds, 255 students - all experiments but only from a distance.

To the question "If you would have a chance to choose this course again, which topics would you like to add?"- All students have answered that they have liked the topics from everyday life and ecological chemistry with 
historical background and chemical background of touristic places.

To the question "Did you like an attempt to integrate the Scientific Tourism with the topics which were discussed during the course?" the answers were:

a) Yes - 800 answers;

b) No - 0 answers;

c) Other - 0 answers.

To the question "Did you like an attempt to integrate the history of chemistry with the topics which were discussed during the course?" the answers were:

a) Yes - 800 answers;

b) No - 0 answers;

C) Other - 0 answers.

To the question "Was the course represented clearly?" the answers were as follows:

a) Yes - 523 answers;

b) No - 277 answers;

c) Other - 0 answers.

To the question "Had this course changed your opinion about chemistry" the answers were as follows:

a) Yes - 361 answers;

b) No - 208 answers;

c) Other - 231 answers (The main cause was that their attitude to chemistry had changed, but they still don't want to make chemistry to be their profession).

If we process our results within the scopes of matrices theory [Gverdtsiteli.1996; Kupatadze, Gverdtsiteli. 2011] we get the visualized data. For example: the distribution of the answers to the question "Had this course changed your opinion about chemistry" can be presented in a form of a diagonal matrix:

$$
\mid \begin{array}{ccc}
361 & 0 & 0 \\
0 & 208 & 0 \\
0 & 0 & 231
\end{array} \|
$$

The specifics of the difference between distributions of the answers can be shown in numbers as the value of the determinant of corresponding matrices.

\section{CONCLUSIONS:}

The presented results of the experiment show that such a method of teaching chemistry makes positive changes in students attitudes. According to opinion research data, the attitude towards chemistry has improved, although part of them are not ready to choose chemistry as their profession. The outcome is promising, it means that active future works in this direction have chance to be successful.

\section{REFERENCES:}

1) ICCECRICE 2012 ;

2) ICHSTM 2013;

3) Ingo Eilks; Avi Hofstein. Teaching Chemistry - A Studybook A Practical Guide and Textbook for Student Teachers, Teacher Trainees and Teachers. Sense Publishers, 2013, p.67.

4) Greenberg, A. From Alchemy to Chemistry in Picture and Story. John Wiley\&Sons, INC., Publication, 2007, p.51.

5) Sutton, R., Rockett, B., Swindells, P. Chemistry for the Life Sciences. Taylor\&Francis Group, 2008, p.45.

6) Gabriele Ferrario, Global histories of chemistry, Lapis Lazuli, Ultramarine Blue and their Journey through Centuries and Cultures. CHSTM 2013.

7) Laarman, J. G. and Perdue, R. R., Tropical science and tourism. Annals of Tourism Research 16, 2, 1989, p.205 cited P.West.,Tourism as Science and Science as Tourism., Current Anthropology 49, 4, 2008, p.597.

8) Azimov, A. History of Chemistry. Press "Мир". Moscow. 1983.

9) Begadze,G. Regions and their socioeconomic growth. Edited by Cezary Mądry. University of Adam Mickiewicz. 2013. P.181. 10)Begadze,G. Exotic Tourism of Georgia. Report at the International conferenceSciebtific Tourism. Vilnius VIKO university.2013. November.

11) Kupatadze,K. Is love a chemistry?! (Collection of scientific-popular articles in 
chemistry published in the internet journal for teachers

http://www.mastsavlebeli.ge/). 2012-2014

Universaly

Press. Tbilisi. 2014.

12) Gverdtsiteli, M. The Contiguity Matrices of Molecular Graphs and their modifications. Tbilisi University Press. 1996. P.23.
13) Kupatadze,K.Gverdtsiteli,M. Theoretical investigation of the isomerization of glucose into fructose within the scope of mathematical and quantum chemistry. ournal of Biological Physics and Chemistry (JBPC), V.11, \#2. 2011. p.60-63.

PERIÓDICO TCHÊ QUÍMICA • www.periodico.tchequimica.com • Vol. 11 N. 22.

- ISSN 1806-0374 (impresso) • ISSN 1806-9827 (CD-ROM) • ISSN 2179-0302 (meio eletrônico)

(C) 2014. Porto Alegre, RS. Brasil

The Periódico Tchê Química (ISSN: 1806-0374; 2179-0302) is an open-access journal since 2004. Journal DOI: 10.52571/PTQ. http://www.tchequimica.com. This text was introduced in this file in 2021 for compliance reasons.

OPEN ACCESS. This article is licensed under a Creative Commons Attribution 4.0 (CC BY 4.0) International License, which permits use, sharing, adaptation, distribution, and reproduction in any medium or format, as long as you give appropriate credit to the original author(s) and the source, provide a link to the Creative Commons license, and indicate if changes were made. The images or other third-party material in this article are included in the

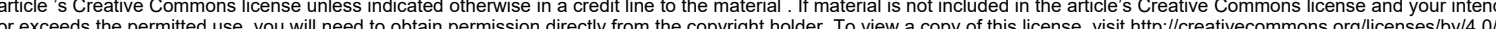
exceeds the permitted use, you will need to obtain permission directly from the copyright holder. To view a copy of this license, visit http://creativecommons.org/licenses/by/4.0/. 